\title{
Author Correction: Chemokine receptor trafficking coordinates neutrophil clustering and dispersal at wounds in zebrafish
}

Caroline Coombs, Antonios Georgantzoglou (1D, Hazel A. Walker, Julian Patt (1), Nicole Merten (1), Hugo Poplimont (1), Elisabeth M. Busch-Nentwich (1D, Sarah Williams, Christina Kotsi, Evi Kostenis (1) \& Milka Sarris (1)

Correction to: Nature Communications https:/doi.org/10.1038/s41467-019-13107-3, published online 14 November 2019.

The original version of this Article contained an error in the Supplementary Information file, in which Supplementary Fig. 7 was inadvertently reproduced to overwrite Supplementary Fig. 12, resulting in the absence of intended data. The HTML has been updated to include a corrected version of the Supplementary Information.

Published online: 21 January 2020

\footnotetext{
(c) (i) Open Access This article is licensed under a Creative Commons Attribution 4.0 International License, which permits use, sharing, adaptation, distribution and reproduction in any medium or format, as long as you give appropriate credit to the original author(s) and the source, provide a link to the Creative Commons license, and indicate if changes were made. The images or other third party material in this article are included in the article's Creative Commons license, unless indicated otherwise in a credit line to the material. If material is not included in the article's Creative Commons license and your intended use is not permitted by statutory regulation or exceeds the permitted use, you will need to obtain permission directly from the copyright holder. To view a copy of this license, visit http://creativecommons.org/licenses/by/4.0/.
}

(C) The Author(s) 2020 